\title{
Çevrimiçi Oyunlarda Eşitlik Arayışı: Minecraft YouTube Dizi İçeriğinde Fakir Köylü Kötü Kalpli Zengine Karşı
}

\author{
Ayşe Aslı SEZGIN**, Kamile ELMASOĞLU**
}

Öz

Son yıllarda internet kullanımının gençler ile ilişkisi kapsamında yapılan çalışmalarda genellikle, bağımlılık, siber zorbalık konularının ön plana çıktığı gözlenmektedir. Bu çalışma, konuya farklı bir bağlamda yaklaşmayı amaçlamaktadır. Bu nedenle, yeni medya içeriğinin üretilmesi noktasında genç nesli aktif bir konuma yerleştiren ve tüm dünyada ilgi uyandıran bilgisayar oyunu Minecraft örnek olarak seçilmiştir. Yaratıcılık ve yeniden üretimi ön plana çıkartan oyun, bunun yanı sıra toplumu zengin-fakir şeklinde sınıfsal bir temsille yansıtmaktadır. Bu çalışmada, çalışmanın kapsamını da oluşturan, YouTube Türkiye video paylaşım sitesindeki Minecraft zenginfakir içeriği, yapısal anlatı analizi yöntemiyle, incelenmiştir. Aktivistlerin belirli bir soruna yönelik kamuoyu oluşturmaları sürecinde önemli bir rol üstlenen yeni medya, bu çalışmada da özellikle genç kullanıcıların zengin-fakir şeklindeki sınıfsal temsile yönelik oluşturdukları içeriğin aktarıcısı konumundadır. "Kötü kalpli zengin”, vurgusu ile zengin olana karşı sürekli bir mücadele içinde olan kullanıcıların kurguladıkları içerik incelendiğinde, Fakir kimliğinin Zengin karşısındaki ezilişi ve karşılığında direnişinin bu içerikler vasıtasıyla da aktarıldığı dikkat çekmiştir.

Anahtar Kelimeler: Aktivizm, Dijital aktivizm, Kimlik temsili, Minecraft, ZenginFakir

\section{Seeking for Equality in Online Games: The Poor Peasant against the Black-Hearted Rich Man in Minecraft YouTube Series Content}

\section{Abstract}

In recent years, it is observed that generally addiction and cyber bullying subjects have been prominent in the studies about the relationship of internet usage with young people. This study aims to approach the subject in a different context. For this reason, Minecraft, which is a computer game that places the young generation in an active position in terms of producing new media content and attracts attention all around the world, has been selected as a sample. In this study, Minecraft's rich and poor content, which is also the scope of the study, in the video sharing website YouTube Turkey was studied through the structural narrative analysis method. The new media, which plays an important role in the process of activists' creating public opinion on a specific issue, is in

\section{Özgün Araştırma Makalesi (Original Research Article) \\ Geliş/Received: 06.01 .2020 \\ Kabul/Accepted: 23.04 .2021 \\ DOI: https://dx.doi.org/10.17336/igusbd.668855}

* Doç. Dr., Çukurova Üniversitesi, İletişim Fakültesi, İletişim Bilimleri Bölümü, Adana, Türkiye, E-posta: aaslisezgin@gmail.com ORCID https://orcid.org/0000-0002-4557-7351

${ }^{* *}$ Ar. Gör. Dr., Ankara Hacı Bayram Veli Üniversitesi, İletișim Fakültesi, Halkla İlișkiler ve Tanıtım Bölümü, Ankara, Türkiye, E-posta: kamileelmasoglu@gmail.com ORCID https://orcid.org/0000$\underline{0003-3811-3038}$ 
the position of the transmitter of the content which especially young users create for class representation in the form of rich-poor. When the content built by the users, in which there is an ongoing struggle against the rich with an emphasis on the black-hearted rich, was examined, it was noted that the identity of the poor is oppressed by the rich and that the ensuing resistance by the poor is transmitted through these contents.

Keywords: Activism, Digital activism, Identity representation, Minecraft, RichPoor

\section{Giriş}

Yeni medyanın "yeni" oluşuna ilişkin açlklamalarda genellikle teknolojik gelişmelerin altı çizilmektedir. İnternetin etkisiyle yeni bir boyut kazanan geleneksel medya, teknolojik gelişmelerle birlikte toplumsal anlamda da farklılıkların yaşanmasında etkili olmuştur. Medyanın etkisi altındaki toplum da bu dijital gelişmelerle ortaya çıkan "yeni medya" vasıtasıyla yeni bir görünüme sahip olmuştur. Toplumsal ilișkilerden, kültürel gelişim sürecine kadar bu etkiler toplumsal yapıda gözlenebilmektedir (Livingstone, 1999).

Yeni teknolojiler vasıtasıyla kimliklerin oluşumu, bedenlerin temsili, toplumsal etkileşim süreci, nesiller arası diyalog ve gençliğin doğası yeniden incelenmektedir. Yeni teknolojilerin etkileşimli kullanımı, kimlik temsillerinin oluşumunda bir model ortaya çıkartmaktadır. Bu yeni ortamda gençler, fikirleri, etkinlikleri ve görüntüleri yeniden, kendi bakış açılarıyla şekillendirmektedir. Kimi zaman bu yeni içerikler gençlerin kendilerini diğerlerine yansıtmada aracı olmaktadır (Weber \& Mitchell, 2008).

Etkileşim ve katılıma imkân tanıyan yapısıyla yeni medya, gençlerin birbirleriyle iletişim kurmalarına, kendi içeriklerini yaratmalarına yönelik farklı imkânlar sunmaktadır. Toplumsal yaşamın her alanına etki eden bu yeni ortam, zamanla daha da yaygınlaşarak çocukların ve gençlerin muhtemel her ortamda erişimine uygun hale gelmiştir (Montgomery, 2000). Bugün artık gençler özellikle bu oyunlar vasıtasıyla okuldan arta kalan zamanlarında vakitlerini geçirmekte, bu ortamda kendi oyun içeriğini oluşturmakta, kurguladıkları oyun karakterleri vasıtasıyla farklı kimliklerin temsilini kendi bakış açılarıyla yansıtmaktadır.

Haziran 2007'de New York'ta düzenlenen Games for Change Festival'de (Değişim için Oyun), sanal aktivizm konusu aktivistler tarafından tartışılmıştır. Festivalde oyunlar, "farkındalık yaratan", "en iyi dönüşümü amaçlayan", "en iyi toplumsal bakış açısını yansıtan" oyunlar olmak üzere üç farklı başlık altında incelenmiştir. Farkındalık yaratan oyunlar, önemli toplumsal konulara yönelik ilgi çekmeyi amaçlarken, dönüşümü hedefleyen oyunlar gerçek dünyada somut bir değişimi önermektedir. Toplumsal bakış açısına ilişkin oyunlarda ise belirli bir yorum çerçevesinde (bazen bir sanatçı veya düşünür de olabilir) önemli toplumsal konularda yeni düşüncelerin yaratılması amaçlanmaktadır (Schreiner, 2008). Bu çerçevede incelendiğinde toplumsal bakış açısını yansıtarak, farkındalık yaratmayı ve toplumsal dönüşümü amaçlayan oyunların, temel hedef kitlesini de oluşturan gençler tarafından üretilen içeriğinde de bu amaçlara ilişkin bulgular dikkat çekmektedir.

Çevrimiçi oyunlar, film endüstrisiyle birlikte önemli bir sektör olarak değerlendirilmekte (Flanagan, 2006), son yıllarda yapılan akademik araştırmalarda, çevrimiçi oyunların toplumsal yaşamdaki etkileriyle ilgili sorgulamalara yer verilmektedir. Bu oyunlar artık, dünyanın dört bir yanından insanları birbirine bağlayarak paylaşılan farklı bir deneyimin yaşandığı ortamlar olarak dikkat çekmektedir. Sivil katılım, toplumsal sermaye, yüz yüze etkileşimlerin değişiklik göstermesi gibi araştırma soruları için bu oyunlar birer inceleme konusu olarak değerlendirilmektedir 
(Williams, 2006). Bu çalışmada da çevrimiçi oyunlara yönelik, oyun içeriğinde yansıtılan toplumsal sınıf ve kimlik temsiline yönelik bir inceleme yapılmıștır.

Çevrimiçi ortamdaki aktivist hareketler yeni toplumsal ve politik ilişkilerin üretilmesine yardımcı olmaktadır. Çevrimiçi oyunlar da bu aktivist hareketlerin gerçekleştiği alternatif temsil ortamları olarak dikkat çekmektedir. Yeni teknolojileri kullanan farklı birey ve gruplar böylece alternatif temsiller de sunmaktadır (Kahn \& Kellner, 2004; Williams, 2006). Özellikle oyunda farklı karakterlerin olması ve bunların çoğu zaman dünyanın farklı bölgelerindeki insanlar tarafından kullanılması, oyuncuların birbirleriyle kurdukları toplumsal etkileşim, bu oyunların popülaritesini arttırmıştır.

Bu çalışmada yeni medyanın önemli ortamlarından biri olan video paylaşım sitesi YouTube'da, Minecraft oyunu için kullanıcılar tarafından hazırlanan ve Türkçe içerikle "Minecraft dizileri, skeçleri" şeklinde isimlendirilen, en çok izlenme oranına sahip içerikler anlatı analizi yöntemiyle incelenmiştir. Oyunun özellikle toplumsal kimlik temsillerini yansıtma şekli, Zengin-Fakir kurgusu içerisinde sürekli olarak zengin olana karşı bir mücadele halinde olan Fakir'in konumu dikkat çekmektedir.

Çalışmada incelenmek üzere seçilen Minecraft oyunu ile ilgili literatürde daha önce gerçekleştirilmiş çalışmalar tarandığında, "eğitim" başlığı altında özellikle yaratıcılık, tasarım, matematik ve dil eğitimi konusunda Minecraft'ın örnek olarak incelendiği çok sayıda araștırma (Short, 2012; Bos vd., 2014; Schifter \& Cipollone, 2013; Brand \& Kinash, 2013) ile birlikte konuyu farklı bir yönden inceleyerek, dijital ortamdaki kültürel ve toplumsal inşayı ve dijital vatandaşlığı konu edinen çalışmalara rastlanmıștır (Niemeyer \& Gerber, 2015; Hill, 2015).

Türkiye'de Minecraft'a ilişkin doğrudan, oyunu örnek olarak seçen akademik bir araștırmaya rastlanmamıștır. Ancak oyuna dair bilgilerin aktarıldığı çalışmalara rastlanmış, bunların ise çevrimiçi oyunlara yönelik "bağımlılık" konusundan (Yücel \& Şan, 2018; Alper vd. 2015) ve Minecraft'ın öğrenme amaçlı kullanımından söz eden çalışmalar olduğu tespit edilmiştir (Çağlar \& Kocadere, 2015; Saygıner \& Tüzün, 2017).

Bunların yanı sıra çevrimiçi oyunlara yönelik Türkiye'de dikkat çekici araștırmalardan da alana katkıları dolayısıyla burada söz etmek gerekir. Oyunların, kültür endüstrisi kapsamında bir ürün olarak değerlendirildiği ve farklı bir sektör olarak dijital oyun sektörünü inceleyen araştırmalar (Binark \& Bayraktutan Sütçü, 2008; Binark, 2007), oyun türleri ve oyuncuların özelliklerine ilişkin ayrıntılı değerlendirme yapan çalışmalar (Binark \& Bayraktutan, 2011), bunlardan bazılarıdır.

$\mathrm{Bu}$ çalışmada daha önce gerçekleştirilmiş çalışmalardan farklı bir şekilde, Minecraft oyununa yönelik olarak hazırlanmış YouTube video içeriği incelenmek üzere seçilmiş ve oyunun özellikle yeni medyadaki içerik oluşturma sürecinin neticesinde kullanıcılar tarafından kurgulandığı vurgulanmıştır. Yeni medya ortamında, çevrimiçi bir oyun vasıtasıyla dile getirilen toplumsal eşitsizlik, çalışmada Minecraft oyun içeriği özelinde incelenmiştir.

Çalışma ayrıca daha önce gerçekleştirilmiş araştırmalardan farklı olarak, çevrimiçi bir oyun içeriğindeki anlatılar vasıtasıyla bu gerçekliğin yansıtılmasını araştırması yönünden de önem taşımaktadır. Bu doğrultuda çalışmanın varsayımlarından ilkini "Minecraft oyununa dair yeni medya içeriğinde kullanıcılar, toplumsal süreçteki eşitlik arayışına yönelik aktivist eylemlerini, yeni bir dil ve kurgu aracılığıyla aktarmaktadır" şeklinde belirtmek gerekir. Çalışmadaki bir diğer varsayım da "YouTube Türkiye video paylaşım ağında aktarılan Minecraft oyununa ilişkin dizilerde, Zengin-Fakir șeklinde toplumsal sınıflara yönelik bir kurgu gerçekleştirilerek, bu kurgu içerisinde, Zengin karşısında ezilen Fakir'in mücadelesi ve direnişi, zengin olanı olumsuzlayarak ön plana çıkartılmıştır" şeklindedir. 


\section{KAVRAMSAL ÇERÇEVE}

\subsection{Yeni Medyada Aktivizm-Dijital Aktivizm}

İnternet, bilgiye anlık erişim sağlarken, mevcut bilginin kullanımını ve yayınlamasını, farklı kesimlerle kolaylıkla diyalog kurulmasını, çeşitli etkinliklerin planlanıp örgütlenmesini ve karar alım mekanizmalarının etkilenmesini kolaylaştırmaktadır. Yeni medya ise internet web sayfaları, elektronik posta listeleri, sohbet odaları ve tartışma grupları gibi çok çeşitli, birbiriyle ilişkili ve farklı iletişim ortamlarını kapsamaktadır (Kalafatoğlu, 2015). Yeni medya, internetle birlikte kullanıma girmeye ve gelişmeye başlamıștır. Bu süreç, öncelikle, elektronik posta iletişimi (e-posta) düzeyinde başlamıştır ve MSN; Messenger, GTalk, Facebook, Myspace, Twitter gibi sanal iletişim ortamları ile zenginleșmiștir. Bu yeni iletişim aracı ile birlikte insanlara, yeni sosyal alanlar açılmıştır (Güngör, 2013).

Yeni medya bu yeni sosyal alanlarla birlikte aktivist bir birey prototipinin olgunlaşarak ortaya çıkmasını sağlamıştır. Bu aktivist birey, yeni medyayı, geçen yüzyılın arka planı ile birlikte değerlendirmektedir. Ayrıca, yeni medya ortamı, toplumsal hareketler açısından bireylerde aktivist bir ruh sağlamanın yanı sıra demokratik katılım ve özgürlüğün gelişmesine de katkıda bulunmaktadır (Babacan, 2015). Özellikle, farklı toplumsal sorunlar etrafında hemfikir olan çeșitli aktivist gruplar, sanal platformlar oluşturarak bu sorunlar için çözüm arayışına girmektedir (Çakır, 2017). Aktivistler için yeni medyanın yerine getirdiği rol ve ișlevler incelendiğinde, organizasyon, koordinasyon, iç tartışma ve karar verme șeklindeki bazı roller ile mobilizasyon, bir kamusal alana katkıda bulunma, alternatif veya bağımsız iletişim kanallarının oluşturulmasını sağlama șeklinde sonuçlar elde edilecektir (Cammaerts, 2015).

Günümüzde toplumsal hayat pratikleri de internet temelli teknolojilerden yararlanmaktadır. Söz konusu hayat pratiklerinden biri de bireylerin internet teknolojilerini kullanarak duygu, düşünce ve tepkilerini ifade ettikleri bir biçim olarak "dijital ortamda yürütülen her türlü aktivist faaliyeti" tanımlamak için kullanılan dijital aktivizmdir (Yegen, 2014; Karagöz, 2013).

Dijital aktivizm "internet aktivizmi", "e-aktivizm", "siber aktivizm" gibi farklı aktivizm türlerinin internet kullanımına verilen genel bir terim olarak literatürdeki yerini almıştır (Uçkan, 2012). Dijital aktivizm, internet üzerinde bir araya gelen bireylerin, savunulan değere ilişkin mesajları birleştiren bir iletişim kampanyası etrafında, belirli eylemleri gerçekleştirmek amacıyla örgütlenmesini amaçlamaktadır (Kocabaş \& Çetin, 2015). 1990'lı yıllarda internetin aktif olarak kullanılmaya başlanmasıyla, geleneksel medya yerine, geniş kitlelerin katılımını teşvik eden internetin özellikle toplumsal hareketler için demokratikleștirici etkisi üzerinde araștırmalar yapılmıștır (Schradie, 2018). Ancak zamanla bu etkinin eleștirel bir şekilde aktarıldığı çalışmalar da dikkat çekmeye başlamış, slacktivism-clicktivism gibi kavramlar da bu çalışmalar neticesinde gündeme gelmiştir Bazı araștırmalarda da vurgulandığı gibi bireylerin belirli eylemleri gerçekleştirmek için örgütlenmesi, antidemokratik eylemleri ve aktörleri de güçlendirmekte, bu da dijital aktivizmin olumsuz etkileri arasında değerlendirilmektedir (Ekman, 2014). Bu konuda dijital aktivizme yönelik daha çok eleştirel çalışmalarda yer alan slacktivizm ve clicktivizm kavramlarından da kısaca bahsetmek gerekir. Dijital tembellik (slacktivism) ve dijital tıklamacılık (clicktivism) kavramları aktivizmin sadece internet üzerinde içerik üretip, paylaşım yapmaya indirgendiğine dikkat çekmektedir. Bu durumda dijitalleşen aktivizm, amacından uzaklaşarak etkisini yitirmektedir (Topbaş \& Doğan, 2016). 


\subsection{Oyun, Çevrimiçi Oyun ve Bu Oyunlara Yönelik Farklı Bir Bakış Açısı}

Gerçek dünyaya göre biçimlenen alternatif dünyalar olarak oyunlara, tarihsel süreçte toplumların her kesiminde rastlanmıştır. En ince ayrıntısına kadar kurallara uyarak oynanan oyunların türü toplumsal sınıfa, cinsiyete, etnik özelliklere veya yaşanılan yere bağlı olmuştur (Heywood, 2003). Zaman içerisinde de toplumlar tarafından sürekli yenilenen, yeniden üretilen "oyun”, yaşama benzer özellikler taşıyan, ikinci bir yaşam olarak da tanımlanmıştır (Cengiz, 1997).

Genel olarak "dijital oyun", "bilgisayar oyunu”, "sanal oyun” şeklinde adlandırılan, bu çalışmada ise "çevrimiçi oyun" olarak ifade edilen oyunlar da geleneksel anlamdaki oyunların, toplumsallaştırma özelliğini internet ortamında sürdürmektedir (Binark, 2007). Dijital oyunların içerisinde konsol ve PC oyunlarıyla birlikte değerlendirilen çevrimiçi oyunlar, bir ağ çerçevesinde oynanmaktadır. İlk kez 1950'lerde görülmeye başlayan bilgisayar ortamındaki oyunlar, 1960'ların sonlarında kitleselleşmeye başlamıştır. A $\breve{g}$, aksiyon, macera, rol yapma/canlandırma, strateji gibi farklı başlıklar altında sınıflandırılan bu oyunlar, günümüzde her yaștan insanın ilgisini çekmektedir (Karahisar, 2013).

Bu çalışmada örnek olarak seçilen Minecraft oyununda da rol yapma kategorisi altında, katılımclar oyundaki herhangi birinin rolünü üstlenmektedir. Bu kategorideki oyunlarda oyuncular tamamen doğaçlama bir şekilde karakterleri canlandırmaktadır. Rol yapma oyunlarında belli bir senaryo ya da hikâye, oyuncular tarafından yaratılarak oynanmaktadır. Çevrimiçi ortamdaki bu oyunlara dışarıdan çok sayıda kişi katılabilmektedir. Bu oyunlar vasıtasıyla sanal dünyada gerçek bir hayat sunulmaktadır (Karahisar, 2013; Demirbaș, 2017).

"Oyun" kavramıyla ilgili literatür tarandığında, kavramın nasıl tanımlanacağı konusuna odaklanan "oyun çalışmaları" karşımıza çıkmaktadır. Oyun kavramının sınırlarının belirlenmesi konusunda farklı değerlendirmelerin yapılması oyun çalışmalarında da farklı görüşleri ortaya çıkartmıștır. Bu görüşler içerisinde ilk etapta dikkat çeken, oyunu biçim olarak ele alan ludoloji çalışmaları ile özellikle yeni medyada oyun konusuna odaklanan dijital anlatı merkezli çalışmalardır (Demirbaş, 2017).

Ludoloji çalışmalarında önemli bir isim olan Hollandalı tarihçi Huizinga (2006), oyunun biçimsel önemini "her oyun bir anlam taşır" düşüncesi ile vurgulamıștır. Uygarlığın başlangıcını "oyun" ile belirleyen Huizinga, akıllı insan (homo sapiens) kavramını kendi bakış açısıyla değerlendirerek, oyun oynayan insan (homo ludens) kavramını tartışır (Çalış, 2017). Huizinga'ya göre oyunda kendine özgü, gerçek hayattan bağımsız bir alan oluşturan oyuncu, bu alana kendine özgü sınırlar çekerek kutsallık kazandırır. Kendi kuralları olan bu özel alanda oyuncu kendisine geçici bir dünya yaratır. Bu dünya içerisinde bir mücadele ve bu mücadelenin kaynağının temsili bulunmaktadır. Huizinga böyle bir oyunu biçimsel olarak incelediğinde özünde "başka türlü olmak" bilincinin yer aldığını, oyunun egemenlik kurma isteğini gerçekleştirmede önemli bir araç olduğunu vurgular (Olgun, 2008; Çalış, 2017).

\subsection{1. Çevrimiçi Oyunlarda Toplumsal Sınıf ve Kimlik Temsili}

Özellikle postmodern dönem ile birlikte sıkça tartışılmaya başlayan "kimlik" kavramı, sürekli olarak değișmekte ve bulunduğu anın gereksinimlerine göre yeniden biçimlenmektedir (Baştürk Akça, 2007). Diğerleri ile yapılan karşılaştırmadan, ötekine yönelik algılardan hareketle tanımlanan kimliğin toplumsal yönü, bireyin üyesi olduğu grubu, bu gruptaki olayları ve grubun diğer gruplarla ilişkisini algılamasına yardımcı olur (Minibas Poussard \& Bastounis, 2008). 
Küreselleşme ile birlikte kimliklerin belirleyici eğilimleri ile şekillenen yaşamlar, bilgi teknolojisi devrimi ve yeniden yapılanan kapitalizm, yeni bir toplum biçimini "ağ toplumu" olarak bize sunmaktadır. Özellikle ekonomik faaliyetlerin stratejik olarak belirleyici olduğu küreselleşme ile birlikte bireysel emek, kültür, iletişim ortamları da yeniden şekillenmiștir. Kimlik ise bu ortamda bireyin deneyimlerinin kaynağında yer almaktadır. Kimliklerin inşasında tarihten, ortak hafızadan, güç aygıtlarından söz edilmektedir (Castells, 2003). Bir "güç" olarak kimlik, bireysel ve toplumsal anlamdaki aidiyetleri ifade etmektedir (Yegen \& Aydın, 2018). Castells'in (2006) meşrulaștırıcı kimlik, direniş kimliği ve proje kimliği olarak incelediği (Akt. Yegen \& Aydın, 2018), kimliklerden direniş kimliğinde birey, benimsediği bu kimlik vasıtasıyla bir konuda direniş gösterir. Bu direnişte, karşı koyuşta, var olana yönelik bir itiraz yer almakta, temelinde eşitlik ve özgürlük talebi bulunmaktadır (Yegen \&Aydın, 2018). Kimliklerin direnişine sebep olan özgürlük ve eşitlik talebiyle ilgili olarak, toplumsal sınıfların tarihsel süreçteki direnişleri üzerinden de bir değerlendirme yapmak mümkündür.

Tüm toplumların tarihinde yer alan sınıf kavgalarında, özgür insan ve köle, ezen ve ezilen arasında kimi zaman açık, ancak sürekli devam eden bir mücadele olduğu gözlenir. İlk çağlarda başlayan toplumun farklı mevkilere göre derecelendirilmesi, farklı mücadelelerin de yaşanmasına neden olmuştur (Marx, 1968). Birey de kendisini ve toplumsal kimliğini, belirli bir toplumsal sınıfın parçası olarak konumlandırır. Çoğu zaman birey olarak değil, belirli toplumsal bir sınıfın üyesi olarak hareket eder. Zamanla bu sınıfın bir üyesi olarak özdeşleşir ve toplumsal kimliği oluşur. Böylece toplumsal kimlik bireyin üyesi olduğu sınıf içerisinde doğar (Demirtaş, 2003). Özellikle modernleşmeyle birlikte, bu sürece ilişkin eleștirel yaklaşımlarda sınıfsal oluşuma yönelik değerlendirmeler dikkat çekmektedir.

Modern yaşamın derin problemleri karşısında bireyin yaşadıklarını aktaran Simmel (2005) zamanla birbirine bağlı bireylerden oluşan bir toplumsal yapıdan söz etmiştir. Böyle bir ortamda da "para" her șeyin belirleyicisi haline gelmiştir. Zenginlerin nesnelerle ilişkisi paraya dayanmaktadır (Simmel, 2005). Bu birbirine bağlılık, dayanıșma kavramının da sorgulanmasına neden olmuştur. Modernliğe ilişkin çözümlemesinde Durkheim da kapitalizmin egemen üretim biçimi haline geldiği toplumlarda dayanışmanın organikleşmesiyle birlikte sınıf ve statü farklılıklarının ortaya çıktığını belirtir (Kaya, 2012). Modernleşmeyle birlikte kapitalist bir seçkinler sınıfının oluşumu gerekli görülmeye başlamıştır. Foucault'nun modernlik düşüncesinde ise toplum, yalnızca zengin ve fakirler ile sömürgeci ve sömürgeler arasındaki bölünmüşlükten dolayı birbirine yabancı mücadeleleri içerdiği şeklinde değerlendirilmiştir (Touraine, 2010). Modernleşmeye yönelik eleştirilere paralel olarak bugün yeni medya içeriğinde toplumsal kimliğin sunumuna yönelik yaklaşımlar da dikkat çekmektedir.

Toplumsal kimliğini farklı ortamlarda temsil eden ve yansıtan birey için günümüzde yeni medya içeriği de bu ortamlardan biri olarak değerlendirilmelidir. Geleneksel medyada içeriğe müdahale imkânı olmaksızın izleyici, dinleyici, okuyucu konumunda olan birey, yeni medyada etkileşimli bir yapıda kendi içeriğini oluşturabilmektedir. Çevrimiçi oyunlar da özellikle gençlerin içerik oluşturmaları noktasında önemli bir örnek olarak dikkat çekmektedir.

Bir kitabın, gazete haberinin, film senaryosunun içeriğine müdahale edemeyen birey, çevrimiçi oyunlarda farklı programlar ve modlar vasıtasıyla kendi isteklerine göre özel bir içerik oluşturabilmektedir. Bu noktada özellikle oyuncunun içerisinde bulunduğu toplumsal yapı, sahip olduğu özellikler, ona neyin çekici geldiği, nelerden zevk aldığı ve eğlendiği önemli bir etken olarak değerlendirilmelidir. Oyuncu gerçek olmadığını bildiği bu ortamda oluşturulan alternatif gerçekliğe inanmak isteyecektir. Bu nedenle çevrimiçi oyunda yaratılan bu sanal gerçeklik oyuncunun beklentilerine göre şekillenmiş (Bostan \& Tingöy, 2015), oyunlarda yansıtılan yaşam biçimleri incelendiğinde birbirine zıt 
yaşamların ve politik göstergelerin kullanıldığı, yeniden üretilen toplumsal eşitsizliklerin olağan hale getirilerek toplumsal hayatın bir parçası olarak gösterildiği gözlenmiştir (Evren, 2017). Bu yaşam biçimleri içerisinde kurgulanan kimlikler de zitlı̆̆ yansıtan önemli unsurlardır. Zengin-Fakir şeklinde toplumsal sınıfa bağlı olarak aktarılan kimlik temsilleri buna örnek olarak gösterilebilir.

\subsubsection{Minecraft'ta Zengin ve Fakir Karşı Karşıya}

Minecraft, 2009 yllında piyasaya sürülen ve halen geliștirilme aşamasında olan Markus Persson tarafindan tasarlanan bir video oyunudur (Alstad, vd. 2014). Minecraft oyunu, oyuncuların kendi kararlarını kendilerinin aldıkları açık uçlu bir oyundur. Oyunun tipleri arasında gösterilen "Yaratıı" modu oyunculara hayal edebilecekleri her şeyi inşa etmek için sinırsız kaynaklar sunmaktadır. "Hayatta Kalma" modu oyuncuların kendilerini beslemek, barındırmak ve savunmak için dünyayı keşfettikleri ve kaynak araştırması yaptıkları bir oyun tipidir (https://minecraft.net/tr-tr/what-is-minecraft/, 28 Aralık 2018).

Oyun, ağızdan ağıza iletişim ve sosyal medya aracılığıyla, 17,5 milyondan fazla kişi tarafından oynanmaktadır. Minecraft, oyunun nasıl oynanacağı hakkında talimatlar veya öğreticiler sağlamaz; bu nedenle deneyimli oyuncular oyunun nasıl oynanacağını bilir ve videolarını oluşturur. Ardından bunları YouTube gibi video paylaşım ağlarına gönderir. Genellikle oyuncular, akran öğretimi yoluyla oyunun nasıl oynanacağı hakkında bilgi edinirler (Overby \& Jones, 2015).

Şubat 2005'teki kuruluşundan bu yana son derece popüler ve etkili olan YouTube, kültürel, sosyal ve politik anlamda internet kullanıcılarına son yıllarda önemli bir ortam sunmaktadır (Kellner \& Kim, 2010). Minecraft'ın Zengin-Fakir başlı̆̆ı ile oluşturulan içeriği de yine YouTube aracılığıyla, doğrudan kullanıcılar tarafından paylaşılmaktadır. İstediği her şeye sahip olan Zengin karakterine karşın, sürekli aç olduğu için yiyecek arayan Fakir karakteri oyun içeriğinde yer almaktadır. Oyunun bu özelliği ve Zengin karakterinin oyun içindeki konumu, Minecraft'ın yaratıcısı Markus Persson'ın sosyal medyada paylaştığı bir yorum ile değerlendirilebilir. Persson'ın, “Zengin ama mutsuzum. İstediğim her şeye sahip olmam yeni şeyler için çabalamama engel oluyor. Kendimi hiç bu kadar yalnız hissetmemiștim (Independent, 2015)" șeklindeki ifadesi, bir anlamda Minecraft'ın "Kötü kalpli, mutsuz Zengin" karakterini anımsatmaktadır.

\section{YÖNTEM}

Çalışmanın amacı, toplumsal eşitsizliğe karşı kimliklerin temsilinde Minecraft oyunu için kullanıcıların kurguladıkları içeriğin nasıl anlatıldığını incelemektir. Bu anlatı kapsamında, Huizinga'nın oyun kuramı temeliyle, oyuncuların bahsedilen eşitsizliği gidermede özellikle "egemenlik kurma" bilincini vurgulamaları ön plana çıkartılmak istenmiştir. Burada Fakir karakteri için kurgulanan oyun anlatısında kötü kalpli Zengin'e yönelik mücadelesi "başka türlü olmanın" aktarımı şeklinde yorumlanmıştır. Bunun için anlatı analizi yönteminden yararlanılmıştır. Anlatı analizi yöntemi ve bu çalışmadaki kullanımının ayrıntılarını aktarmadan önce anlatı kavramı ve anlatı yaklaşımı (narrative theory) hakkında bilgi vermek gerekir.

Anlatı yaşanan, deneyimlenen bir olay ya da olaylar dizisinin çeşitli iletişim kanalları yoluyla başka kişi ya da kişilerle paylaşılması şeklinde tanımlanırken (Şardağı \& Yılmaz, 2017), olaylar zamansal ve nedensel ilişkilere göre planlı bir düzende sıralanıp metinsel olarak ifade edilmektedir (Işıtan \& Turan, 2014). İletişimin temel dokusunu da oluşturan anlatı, kültürü meydana getiren başlıca unsurlardan biridir. Metinlerin bir toplumdaki değer yargılarını kodlayarak, birey davranışlarını yorumlamada yardımcı 
olan kültürel modeller olduğu savunulduğunda, anlatı çalışmaları da belirli bir kültürdeki değerleri ve sembolleri çözümlemek için kullanılır (Atabek, 1992).

İnsanlarla iletişim kurmada ortak noktalardan biri olarak hikâyeleri değerlendiren anlatı yaklaşımında, insanların yaşam deneyimlerini anlatan doğal hikâyeciler oldukları savunulur. Temelinde inandırıcılığın bulunduğu anlatı yaklaşımında, tutarlılık ise anlatının mantıksal olarak organize edildiğini belirtir ve ahengi sağlar. Tutarlı anlatılarda karakterlerin yaptıklarını yapmak için iyi bir sebepleri vardır. Anlatı yaklaşımı, bir anlatıya anlatıdaki insanlar kim, bu kişilerin anlatıdaki işlevi nedir, bu kişiler anlatıda ne yapıyorlar, neden yapıyorlar, sonuçları nelerdir sorularını yönelterek neden-sonuç ilişkisini saptamaya çalışır (Şardağı \& Yılmaz, 2017).

$\mathrm{Bu}$ yaklaşımdan hareketle gerçekleştirilen anlatı analizinde, insanların hikâye formatında şifreledikleri deneyimlerinin izleri analiz edilir (Uștuk, 2016); olaylar, olayların tekrarı, olay örgüsü ve karakterler gibi unsurlar incelenir (Sözen, 2012). Tüm anlatı metinlerinde bir olay örgüsü ile bunu sunacak bir anlatıcı bulunur. Anlatıdaki olaylar, eylemler, kahramanlar ve onların düşünceleri belli bir bakıș açısıyla aktarılır. Tüm anlatılar kurgusal bir yapıda ve bir yorumlamanın sonucu olarak aktarılır. Anlatı analizi genel hatlarıyla tematik ve yapısal olarak iki ayrı grupta toplanabilir. Ne söylendiği üzerine yoğunlaşan tematik analize karşılık, yapısal analizde nasıl söylendiği araștırılır. Yapısal analizde anlatıcı, deneyim ve olguları anlamlandırarak dış dünyada ne olduğunu inşa eder (Tanyaş, 2014). Yapısal analizde, yapısalcı yaklașımdan hareketle, anlatıdaki görünen anlamla birlikte yüzeyde görünmeyen derindeki yapılar incelenmek istenir. Yüzey ve temel ayrımı ile yapılan bu analizde her ikisinin birbirini tamamladığı düşüncesinden hareket edilir (Güleç, 2014).

Jahn, anlatı yaklaşımına ilişkin araştırmalarını derlediği Anlatıbilim: Anlatı Teorisi El Kitabı (2005) isimli çalışmasında farklı bölümler altında anlatı analizi hakkındaki temel noktaları açıklar. Bu ayrıntılar bir bakıma, anlatı analizinde araştırmacıların takip edecekleri adımları da açıklamaktadır. Bu çalışmada da bu adımlar takip edilerek incelenmek üzere seçilen içeriğin analizini gerçekleştirmek amaçlanmıştır. Ancak bu noktada Jahn'ın anlatı analizinde tespit ettiği sorular, bu çalışmanın içeriği dikkate alınarak geliştirilmiş, yeniden düzenlenmiştir. Bu sorular ve takip edilen yol şu şekilde belirtilebilir:

Tablo 1. Anlatı Analizi Adımları (Jahn, 2005)

\begin{tabular}{|l|l|}
\hline \multicolumn{1}{|c|}{ Anlatı Analizi Soruları } & \multicolumn{1}{|c|}{ Açıklama } \\
\hline $\begin{array}{l}\text { Oyunu kurgulayan oyuncu } \\
\text { kimdir, nasıl özelliklere } \\
\text { sahiptir? }\end{array}$ & $\begin{array}{l}\text { Anlatı analizinde anlatma ile ilgili olarak bu soru yöneltilir. Bu } \\
\text { anlatıcı ne anlatılacağına, nasıl anlatılacağına, neyin anlatılırken } \\
\text { dışarıda bırakılması gerektiğine karar veren kişidir. }\end{array}$ \\
\hline $\begin{array}{l}\text { Oyun içerisindeki anlatı } \\
\text { hangi adımlardan } \\
\text { oluşmaktadır? }\end{array}$ & Olayların kronolojik dizisinin incelenmesidir \\
\hline $\begin{array}{l}\text { Oyun kurgusu içerisinde } \\
\text { gerçekleşen olayların } \\
\text { sebebi ne olabilir? }\end{array}$ & $\begin{array}{l}\text { Burada, olay örgüsünü ortaya çıartabilmek, mantıksal ve } \\
\text { nedensel yapıyı çözmek amaçlanır. }\end{array}$ \\
\hline $\begin{array}{l}\text { Oyun içeriğindeki zaman } \\
\text { nasıl kurgulanmıştır? }\end{array}$ & Anlatıda zaman analizi yapabilmek için bu sorulara yanıt aranır. \\
\hline $\begin{array}{l}\text { Oyunun mekânsal olarak } \\
\text { analizi nasıl yapılır? }\end{array}$ & $\begin{array}{l}\text { Anlatının mekânı da olayın konumlandığı ortam olarak yine } \\
\text { analiz içerisinde incelenir. }\end{array}$ \\
\hline $\begin{array}{l}\text { Oyundaki karakterler } \\
\text { kimler ve hangi } \\
\text { ozzelliklere sahipler? }\end{array}$ & $\begin{array}{l}\text { Analizde karakterler ve karakterleştirme üzerinde de } \\
\text { durularak, kurgulanan karakterlerin özellikleri hakkında bilgi } \\
\text { toplanır. }\end{array}$ \\
\hline
\end{tabular}


Daha önce gerçekleștirilen çalışmalar dikkate alındığında yapısal anlatı analizi konusunda, benzer yapıdaki anlatıların analiz edildiği gözlenecektir. Bu noktada, çalışmaya konu olan içeriğin diğer anlatı metinlerinden farklı yönleri hakkında kısaca bilgi vermek gerekir:

- Minecraft dizileri- skeçleri, kullanıcılar tarafından kurgulanan, yine kullanıcıların yarattıkları mekanlarda geçen olayların, kurgu karakterlerle gerçekleştirildiği anlatılardır.

- İnternetin önemli özelliklerinden biri olan etkileşimli yapı, bu içeriğin de interaktif bir şekilde yani kullanıcıların katılımı ve müdahalesine açı olarak oluşturulmasına imkân tanımaktadır.

- Anlatılar metinsel ifadelerden farklı olarak görsel unsurlarla kurgulanmıştır. Görüntü, ses, müzik gibi unsurlar bu anlatıları klasik anlatılardan farklı kılmaktadır. etmektedir.

- Minecraft oyununa ilişkin içerik, dizi halinde kurgulanarak, bir süreklilik arz

- Kimi zaman birbiri ile iç içe geçen anlatılarda karakterler farklı özellikler taşımaktadır. İçerikte, çoğu zaman direniş kimliğinin ön plana çıktığı karakterlerin birbirleriyle mücadelesi gözlenmektedir.

Bu çalışmada, Tablo 1'de belirtilen anlatı analizi adımları, yeni medyanın bahsi geçen özellikleri de göz önüne alınarak gerçekleștirilmiştir.

\section{BULGULAR}

YouTube Türkiye video paylaşım ağında, çalışmaya konu olan Minecraft oyununa ilişkin, kullanıcılar tarafından hazırlanarak paylaşılan videolar, YouTube arama kutusu yardımıyla belirli özellikler dikkate alınarak listelenmiştir. Arama sözcügü olarak "Minecraft zengin fakir" anahtar sözcüğü kullanılmış, arama sonucu çıkan videolar "görüntülenme sayısı" sıralama ölçütüne göre listelenmiștir. Bu arama neticesinde 5.996 .161 görüntülenme sayısına sahip (Ocak 2019) "Minecraft Zengin Fakir Filmi Gariban Zengin" başlıklı 17 dakikalık içerik (https://www.youtube.com/ watch?v=P6qWeYNvlFw), ilk sırada yer almıştır. 17.000 kişi tarafından beğenilen içeriğe, 1898 kiși yorum yapmıştır. İçeriğin üreticisi "Ben ve Siz" kullanıcı adına sahip bir YouTube abonesidir. 16.965 kişinin takip ettiği kullanıcı, Ocak 2013 tarihinde YouTube video kanalına üye olmuştur. Çalışmaya konu olan bu içerik ise 2 Temmuz 2016 tarihinde paylaşılmıştır.

İçerikte iki oyuncu bulunmaktadır. Minecraft dijital küpleri vasıtasıyla oluşturulan ortamda, Fakir ve Zengin olarak iki ana karakter bulunmaktadır. İçerikte oyuncular tarafından kurgulanan anlatı Tablo 2'deki bilgiler vasıtasıyla analiz edilmiștir. Analizde ayrıca video paylaşımına yapılan yorumlar içerisinden çalışmanın kapsamına uygun olarak seçilen takipçilerin yorumlarından örnekler seçilerek, analize dahil edilmiştir. Böylece, anlatının diğer kullanıcılar tarafından çalışmanın varsayımına (zenginin olumsuzlanarak, fakirin mücadelesinin ön plana çıkarılması) uygun şekilde algılanıp algılanmadığı yönünde bir değerlendirme yapılmak istenmiştir. 
Tablo 2. Minecraft Zengin Fakir Filmi, Gariban Zengin İçeriği Anlatı Analizi

\begin{tabular}{|l|l|}
\hline \multicolumn{1}{|c|}{ Anlatı Analizi Soruları } & \multicolumn{1}{c|}{ Açıklama } \\
\hline $\begin{array}{l}\text { Oyunu kurgulayan oyuncu } \\
\text { kimdir, nasıl özelliklere } \\
\text { sahiptir? }\end{array}$ & $\begin{array}{l}\text { "Ben ve siz" isimli kullanıcı ile “Steve" isimli kullanıcı, } \\
\text { Fakir ve Zengin karakterlerini canlandırmaktadır. }\end{array}$ \\
\hline $\begin{array}{l}\text { Oyun içerisindeki anlatı hangi } \\
\text { adımlardan oluşmaktadır? }\end{array}$ & $\begin{array}{l}\text { Fakir açlıktan uyuyamadığı için komşusu Zengin'den para } \\
\text { istemeye gider. Zengin Fakir'i para istemeye geldiği için } \\
\text { kovar. }\end{array}$ \\
\hline $\begin{array}{l}\text { Oyun kurgusu içerisinde } \\
\text { gerçekleşen olayların sebebi ne } \\
\text { olabilir? }\end{array}$ & $\begin{array}{l}\text { Fakir, evinde eşyası (bir yatağı bile yoktur) ve yemeği } \\
\text { olmadığı için Zengin'den yardım istemeye gider. Yaşadı̆ğ } \\
\text { yerde yardım isteyebileceği tek kişi komşusu Zengin'dir. } \\
\text { Ancak Zengin, daha önce para verdiği fakirler parasını } \\
\text { geri ödemedikleri için Fakir'in isteğini de reddeder. }\end{array}$ \\
\hline $\begin{array}{l}\text { Oyun içeriğindeki zaman nasıl } \\
\text { kurgulanmıştır? }\end{array}$ & $\begin{array}{l}\text { Gece uykusu kaçan Fakir'in uyanıp evden çıkışı ile } \\
\text { başlıyor. Bir gün boyunca sürüyor. }\end{array}$ \\
\hline $\begin{array}{l}\text { Oyunun mekânsal olarak } \\
\text { analizi nasıl yapılır? }\end{array}$ & Olay Minecraft köyünde gerçekleşiyor. \\
\hline $\begin{array}{l}\text { Oyundaki karakterler kimler ve } \\
\text { hangi özelliklere sahipler? }\end{array}$ & Zengin ve Fakir \\
\hline
\end{tabular}

İçerik, Tablo 2'de aktarılan anlatı analizine ilişkin bilgiler doğrultusunda incelendiğinde iki karaktere de ait dikkat çeken ifadeler şu șekildedir:

Fakir: "Karnım gurulduyor, böyle fakirlik olmaz olsun. Bakkala gideyim ama para yok ki! Șurada altın sarısı eve tașınan biri vardı, gidip ona dileneyim. Inşallah bana para verir, fakir görmez! Karnım hep gurulduyor. Gideyim de yatağım olmayan yerde yatayım."

Zengin: "Para mı istiyorsun? Fakirler hep para ister!"

Fakir: "Ben fakir değilim! Evim öyle olabilir ama ben fakir değilim! Fakirlerle dalga geçenleri sevmiyorum! Sen zengin bir insansın neden benimle konuşuyorsun?"

Çocukluk ve ergenlik dönemleri arasında, toplumsal yaşamdaki kişilerin gözlenebilir özelliklerine ilişkin yapılan değerlendirmelerde değişiklikler gözlenmektedir. Özellikle çocukların cinsiyet rollerini, mesleki rolleri daha fazla vurguladıkları dikkat çekmektedir. Yaş ilerledikçe ekonomik farklılıklar, toplumsallaşma sürecindeki çocuklar ve ergenler tarafından "sahip olma" veya "görünüm farklılığı" gibi etkenlerden daha farklı anlamlar kazanmaya bașlar. Zengin-Fakir șeklinde yapılan ayrıştırma bu dönem sonrasında daha çok gözlenmektedir (Leahy, 1981). Bu çalışmada da kullanıcıların kendi oluşturdukları içerik vasıtasıyla "zengin-fakir" șeklindeki sınıfsal ayrımı kurguladıkları gözlenmiștir. Parası olmayan Fakir'e karşı, altın rengi bir evde yaşayan Zengin toplumsal anlamda oldukça farklı bir statüde yaşamaktadır. Açlık, imkansızlıklarla birlikte, ezilmişlik ("Sen zengin bir insansın neden benimle konuşuyorsun?") duygusu ise Fakir kimliğinin yansıtılmasında kullanılmıștır. İçeriğe yönelik yorumlarda da Fakir'in yaşam koşullarına ilişkin ifadelerle bu sınıfsal farklılık vurgulanmıştır.

Yorum 1: "Fakir'in evi böyle olmaz; topraktan olması lazım".

Yorum 2: "Abi Fakir'in evi normalde topraktan olur, seninki neden böyle?"

Yorum 3: "Fakir'in böyle güzel evi olmaz! İmkânsız!" 
Çocukların ve gençlerin toplumsal sınıflara ilişkin değerlendirmelerinde, gelişimsel bir değişimin olup olmadığı sorusu tartışılmaktadır. Toplumsal sınıflara ilişkin değerlendirmelerde farklı ideolojik kaynaklardan beslenen sınıf teorileri farklı etkenleri dikkate alarak tanımlamalar yapmıștır. Ergenlik döneminde sınıfsal değerlendirmelerin inşa edilmesinde etkili olan bu yaklaşımlar, zamanla bireysel eylemlerin şekillenmesinde de önemli rol oynar (Leahy, 1981).

İncelenen içerikteki iki farklı karakterde dikkat çeken, anlatı analizindeki "kim konuşuyor, bunu kim anlatıyor?" sorularının da yanıtı olan anlatıcıların yaşlarıdır. Fakir karakterini canlandıran kullanıcı sesinden de anlaşıldığı kadarıyla 20’li yaşlarındadır. Zengin ise kendisinin de içerikte ifade ettiği gibi 12 yaşındadır. Her iki kullanıcı da çevrimiçi oyunlar konusunda bilgi ve birikim sahibi yeni nesli temsil etmektedir. $\mathrm{Bu}$ noktada, özellikle internet vasıtasıyla toplumsal yaşamda yaşanan değişimin önemli bir sonucu olarak değerlendirilen dijital aktivizmin, incelenen içerik vasıtasıyla farklı bir şekilde gerçekleştirildiği dikkat çekmektedir. Minecraft dizisinde, Fakir'in Zengin karşısındaki direnişi bu kez bir çevrimiçi oyun vasıtasıyla kurgulanarak yansıtılmıştır.

1960'lardaki siyasal iktidarı hedefleyen, ekonomik çıkarların merkezde olduğu ve "eski toplumsal hareketler" olarak adlandırılan hareketlerin yerini, 1970'lerden itibaren ortaya çıkan ve farklı kaygıları dile getiren (ekolojik sorunlar, kadın hakları, azınlıklar, hayvan hakları, barış yanlısı ve nükleer karşıtı hareketler) "yeni toplumsal hareketler" almıștır. Bu hareketlerin aktivistlerinin ise eğitimli, orta sınıf üniversite öğrencileri olduğu belirtilmektedir. Yeni toplumsal hareketler daha çok yaşam kalitesi, eşitlik, bireysel katılım gibi konuları merkeze almaktadır (Karagöz, 2013). Minecraft Zengin Fakir Filmi'nde kurgulanan mekân, karakterlerin dış görünümleri bașta olmak üzere yaşam kalitesindeki farklılıklar, eşitsizlik bu kez farklı bir şekilde çevrimiçi oyun içeriğiyle aktarılmıştır. İçerikteki Zengin karakteri mavi parlak zırhı içerisinde, elinde kılıcı olan ve altın sarısı, meşalelerle aydınlanan bir yolu bulunan çok büyük bir evde yaşamaktadır. Madenleri vasıtasıyla biriktirdiği mücevherlerini evindeki sandıklar içerisinde saklamaktadır. Fakir karakteri ise koyu tenli, sakallı, üzerinde yırtık bir gömlek bulunan, ayakkabıları dahi olmayan bir karakter șeklinde tasarlanmıștır. Fakir'in evi tek katlı ve içerisinde hiç eşyası olmayan küçük bir evdir. Huizinga'nın oyuncuların, kendilerine özgü gerçeklikleri içerisinde kurguladıkları oyun alanları açısından bu ortamlar değerlendirildiğinde, gerçek hayattan bağımsız, kendi sınırları ve kuralları olan bir ortamda Zengin ihtişamı yaşarken, Fakir de bunun tam tersi bir mekânı yaşam alanı olarak kurgular. Bu kurgulama, video içeriğine yönelik bir yorumda şu şekilde aktarılmıştır.

\section{Yorum 4: "Abi sen ne yaptın fakir evi camdan yapılmaz çok saçma olmuş evi bari küçük yapıp odundan yapsaydın!"}

YouTube video paylaşım ağındaki Minecraft dizi içeriğinde, farklı kullanıcıların oyuna katılabilmeleriyle birlikte, paylaşımı ve ortak hareket etmeyi teşvik eden iş birliğine dayalı bir ortam tasarlanmıştır. Burada tüm katılımcılar yoğun olarak çalışıp, işbirlikçi bir ortamda, birbirlerinden destek alarak, ortak hedeflere ulaşabilmek için çabalar (Niemeyer \& Gerber, 2015). İncelenen içerikte Fakir karakteri yaşadığı ortamda zor şartlar altında ayakta kalmaya çalıșmaktadır. Genel olarak benzer içerikteki Minecraft YouTube dizi içerikleri incelendiğinde fakir karakterlerin zengin karakterler karşısında mücadele ettikleri bir ortam kurgulanmıștır. Yaşanılan evler, giyim, ten rengi, kullanılan eşyalar ve söylem incelendiğinde sürekli olarak Zengin'e karşı mücadele eden bir Fakir kimliğinin temsili gözlenmektedir.

Yeni medyanın aktivist hareketleri dijital olarak organize etmesi, farklı biçimlerdeki, farklı içeriklerin bu amaçla kullanılmasını sağlamıştır. Kolektif eylemlere 
yönelik olarak farklı, yaratıcı yöntemler bulup üretme noktasında yeni medya önemli bir araç olarak değerlendirilmektedir. Özellikle görsel unsurların, grafik anlatımın metaforik özelliklerinin kullanıldığı yeni medya içeriğinde (Meriç, 2012) çevrimiçi oyunlar da kendilerine özgü özellikler aracılığıyla aktivist hareketlerin farklı bir bakış açısından değerlendirilmesini sağlamaktadır.

Çalışmada incelenen diğer bir içerik, YouTube video paylaşım ağında 9 0cak 2017 tarihinde yayınlanmış ve 3.165.465 kez görüntülenmiştir. "Minecraft Zengin-Fakir Kötü Kalpli Zengin" başlığını taşıyan içeriğe https://www.youtube.com/ watch?v=NymYcafU6CQ\&t=405s) 3722 kişi yorum yapmıştır. 24.000 kişi tarafından beğenilen içerik 15 dakikalık bir süreye sahiptir. Tablo 3 ile anlatı analizi adımları aktarılan Minecraft dizisindeki ifadeler de dikkat çekmektedir.

Tablo 3. Minecraft Zengin Fakir Kötü Kalpli Zengin İçeriği Anlatı Analizi

\begin{tabular}{|l|l|}
\hline \multicolumn{1}{|c|}{ Anlatı Analizi Soruları } & \multicolumn{1}{c|}{ Açlklama } \\
\hline $\begin{array}{l}\text { Oyunu kurgulayan oyuncu } \\
\text { kimdir, nasıl özelliklere } \\
\text { sahiptir? }\end{array}$ & $\begin{array}{l}\text { "Ahmet oyunda" isimli kullanıcı ile "Zengin Zeynep" isimli } \\
\text { kullanıc, Fakir ve Zengin karakterlerini canlandırmaktadır. }\end{array}$ \\
\hline $\begin{array}{l}\text { Oyun içerisindeki anlatı } \\
\text { hangi adımlardan } \\
\text { oluşmaktadır? }\end{array}$ & $\begin{array}{l}\text { Fakir sabah erkenden uyanarak kendisine yiyecek bir şeyler } \\
\text { bulmaya gider. Bu sırada Zengin'in evinin önünden geçmek } \\
\text { zorunda kalır. Burada Zengin'in tepkisi ile karşllaşır. }\end{array}$ \\
\hline $\begin{array}{l}\text { Oyun kurgusu içerisinde } \\
\text { gerçekleşen olayların sebebi } \\
\text { ne olabilir? }\end{array}$ & $\begin{array}{l}\text { Zengin kendi evini, yaşadığı ortamı, tükettiği yiyecekleri } \\
\text { oldukça farklı bulmakta, Fakir'in bunlara asla } \\
\text { erişemeyeceğini düşünmektedir. Zengin ayrıca Fakir'in fakir } \\
\text { olduğu için okuma yazma bilmeyen bir cahil olduğunu da } \\
\text { düşünür. }\end{array}$ \\
\hline $\begin{array}{l}\text { Oyun içeriğindeki zaman } \\
\text { nasıl kurgulanmıștır? }\end{array}$ & $\begin{array}{l}\text { Sabah erkenden uyanan Fakir'in uyanıp evden çıkışı ile } \\
\text { bașlıyor. Bir gün boyunca sürüyor. }\end{array}$ \\
\hline $\begin{array}{l}\text { Oyunun mekânsal olarak } \\
\text { analizi nasıl yapılır? }\end{array}$ & Olay Minecraft köyünde gerçekleşiyor. \\
\hline $\begin{array}{l}\text { Oyundaki karakterler kimler } \\
\text { ve hangi özelliklere sahipler? }\end{array}$ & Zengin ve Fakir \\
\hline
\end{tabular}

Zengin: "Evimin önünden gider misin? Şunun evine bak ne kadar kötü.

Eminim sen yazmayı da bilmiyorsundur! Ben ne yiyorum o ne yiyor!"

Fakir: "Ben maalesef Fakir Ahmet'im ve odun toplamak zorundayım"

Zengin: "Çalışkan șey! Umurumda değilsiniz! Alın odunlarınızı! Ben gidip

balığımı yiyeyim! Ne kadar çirkin bir adam şu Fakir! Elimi neden ona sürdüm?”

Fakir: "Ben gerçekten çok fakirim..."

Zengin: "Senin yaşadığın yer burası mı? Ne kadar da küçük! Ben burayı köpeklerimin yuvası bile yapmam!"

Aktivistlerin bir soruna yönelik olarak gerçekleştirdikleri eylemler incelendiğinde (gazetecilere mektup yazmak, telefon kampanyaları düzenlemek, sivil itaatsizlik eylemleri, dilekçeler, gösteriler vd.) bunların bugün geleneksel aktivizm yöntemleri olarak değerlendirildiği gözlenir. Aktivistlerin, sorunlu bir şekilde gerçekleștiğine inandıkları, olup bitenlerle ilgili eylemlerinde son yıllarda teknolojinin etkisi hissedilmektedir. İnternetin sağladığı imkanlar aktivist hareketlere yeni bir yaklaşım getirmiștir. Ucuz ve erișilebilir olması, daha kısa sürede daha çok kişiye ulașılması, etkileşimli yapısı interneti bu alanda da tercih edilen bir ortam haline getirmiştir (Sert, 2012). Minecraft dizi içeriği de aynı şekilde, çevrimiçi bir oyun olarak internetin erişim sağladığı her alanda kullanıcıları tarafından oynanabilmekte, oyunla ilgili içerik üretilebilmektedir. Ayrıca oyun hakkında belirtilmesi gereken bir diğer önemli nokta da 
oyun içeriğinde kullanıcıların hayal ettikleri dünyayı, yaşam alanını, olmak istedikleri karakteri tasarlayabilmeleridir.

Minecraft kız ve erkek oyuncuların aynı șekilde ilgisini çeken, içerisinde iş birliğini barındıran ve kullanıcıların yaratıcılığını ön plana çıkartan bir oyun olarak değerlendirilmektedir. Sunulan sanal alanda oyuncular tamamen kendi hayal güçlerini yansıtan bir içerik tasarlamaktadırlar. Son yıllarda okullarda eğitim müfredatında da yer verilen bu oyun 21. Yüzyılda öğrencilerin dijital kültürün bizzat üreticileri olma noktasında giderek artan bir rol üstlenmiştir (Overby \& Jones, 2015). Minecraft, eğitimciler tarafından da gerçek yaşam deneyimlerini öğrencilere sunması nedeniyle tercih edilmektedir (Short, 2012). Bu çalışmada incelenen Minecraft içerikleri de oyuncuların gerçek yaşamı canlandırdıkları, içerisinde toplumsal sınıfların farklı kimlik temsilleriyle aktarıldığı bir kurguya sahiptir. Zengin'in kimliği altın madenleri, büyük ve gösterişli evler, güzel klyafetler, bol yiyecek simgeleri ile betimlenirken; Fakir kimliği ise açlık, koyu ten rengi, yırtık ve eski kıyafetler, eşyasız evler şeklinde betimlenmektedir. Gerçek yaşamda deneyimlenen ayrıntıların oyun vasıtasıyla aktarıldığı ve bu aktarım esnasında da "kötü kalpli Zengin"e karşın "gariban Fakir'in" toplumsal konumu sürekli vurgulanmaktadır. İçeriğe yapılan yorumlarda da bu ayrım aynı şekilde vurgulanmakta kimi zaman eleştirel bir şekilde dile getirilmektedir.

\section{Yorum 1: "Zenginsin ama Zeynep gönlün yok hem o da insan zengin fakirle dalga geçemezsin arkadaşlı kuracaksin fakir olsa da!" Yorum 2: "Fakirin de gönlü zengin unutmayın bunu!}

21. yüzyılda gelişmiş ülkelerin de sorunu olarak değerlendirilmeye başlayan fakirlik olgusu, gelir ve tüketim eksenindeki nicel göstergelerin yanı sıra çok boyutlu bir şekilde değerlendiren farklı bir yaklaşımla da yorumlanmıştır. 1990'lı yıllardan itibaren küreselleşmenin de etkisiyle artan fakirlik olgusu (Özçelik, 2013), bu çalışmada da özellikle belirtilen yılların son dönemlerinde doğarak, dünyayı algılamada küreselleşmenin yoğun etkisi altında kalan yeni kuşakların gözünden, Zengin-Fakir algısı ile birlikte incelenmiștir.

\section{SONUÇ}

Çevrimiçi oyunlar konusunda gerçekleştirilen çalışmalar incelendiğinde, merkezinde "bağımlılık" konusunun yer aldığı araştırmalar dikkat çekmektedir. Ancak ilerleyen süreçte çevrimiçi ortamın etkileşimli yapısı, bu oyunların içerik üretiminde kullanıcıların da aktif konumda olması, oyunlara yönelik farklı bir yaklașımı da gerekli kılmaktadır.

Türkiye'deki literatür incelendiğinde çevrimiçi oyunların yapısı ve oyuncuya ilișkin ayrıntılı değerlendirmelerin yapıldığı çalışmaların sayısının oldukça az olduğu dikkat çekmektedir. Özellikle medya karşısında kullanıcıları pasif gören ana akım yaklaşımların etkisiyle gerçekleștirilen çalışmalar, oyunların farklı bir bakış açısıyla da değerlendirilmesini gerekli kılmaktadır. İçeriğini kullanıcıların oluşturduğu oyunlar, içerisinde bulundukları toplumsal süreçten soyutlanmadan incelenmelidir. Böylece oyuncuların oyun içerisindeki rollerinin yorumlanması da daha net gerçekleştirilebilecektir (Koç, 2017).

Çevrimiçi oyun kavramından önce geleneksel anlamıla "oyun" kavramını incelediğimizde, toplumsallaşma sürecindeki etkisiyle, bu süreçteki sembollerin, rollerin ve kuralların öğrenildiği bir ortam karşımıza çıkacaktır. Rekabet edebilme, rol yapma, ödül ve ceza mekanizmasını öğrenme, dışlanma ya da tam karşıt haliyle bütünleşme şeklinde toplum yaşamına ait olan süreçler hakkında benzer ortamlar oyun ortamlarında 
da yaşanmaktadır (Bağrıyanık, 2018). Huizinga'ya (2006) göre de oyun içerisindeki oyuncuların birbirleriyle ilişkileri, oyuna koydukları kurallar, oyun içinde bir kültür oluşturur. Bu kültürde insan, kendi hayal dünyasını yaratır. Hayal dünyası içinde zevk ve haz duyar (Akt. Öngen, 2017). Çevrimiçi oyunu, kültürel bir meta olarak değerlendirdiğimizde ise kapitalizmin toplumsal yapısını yansıtan bir içeriğe sahip olduğunu belirtmek doğru olacaktır (Kaymas, 2017).

Bu çalışmada incelenen Minecraft oyununa dair YouTube Türkiye video paylaşım ağında yer alan içerik, Zengin-Fakir kimliklerinin temsili çerçevesindeki anlatısı ile dikkat çekmiştir. Bir şekilde kullanıcılarının kurguladığı bir anlatıya sahip olan içerikte, her iki kimliğin konumu, kullandıkları dil, olayların geçtiği ve yine kullanıcılar tarafından tasarlanan mekanlar incelendiğinde, çalışmanın kavramsal çerçevesi kapsamında da incelenen bazı noktalarla ilgili tespitler göze çarpmaktadır.

Çalışmanın "YouTube Türkiye video paylaşım ağında aktarılan Minecraft oyununa ilişkin dizilerde, zengin-fakir şeklinde toplumsal sınıflara yönelik bir kurgu gerçekleștirilerek, bu kurgu içerisinde, Zengin karşısında ezilen Fakir'in mücadelesi ve direnişi zengin olanı olumsuzlayarak ön plana çıkartılmıștır" varsayımına ilişkin değerlendirme yapılmak istendiğinde, oyuncuların kurguladıkları dil vasıtasıyla gerçekleştirilen anlatıda da bu olumsuzlamanın ön plana çıtığı gözlenecektir. İçeriklerde kısıtlı imkanlarla yaşam mücadelesi veren Fakir'in karşısında gücünü yaşadığı mekâna ilişkin ayrıntılarla gösteren bir Zengin vardır. Fakir'e yönelik tavrında her zaman statü farkını vurgulayan Zengin, istediği zaman Fakir'e acıyarak yardım eden kötü kalpli bir karakter kurgusu içerisindedir.

Eleştirel bir yaklaşımla küreselleşmenin, zengin ve fakir arasındaki uçurumun daralmasına yardımcı olmak yerine, zenginin daha zengin, fakirin de daha fakir olmasına neden olduğunu söylemek mümkündür. Böyle bir toplumsal düzene yönelik direniş de kimi zaman küresel boyutlara ulaşmıştır. Daha adil bir yaşam amacıyla insanlar seslerini her ortamda dile getirme kaygısı taşımıștır. Bu ortamlar içerisinde internet de en dikkat çekici olanıdır (Ertuna, 2006). Bu çalışmada da Zengin-Fakir çatışmasında Zengin'e karşı direnişin sergilendiği internet ortamlarından biri incelenmiștir.

Çalışmanın diğer varsayımı olan "Minecraft oyununa dair yeni medya içeriğinde kullanıcılar, toplumsal süreçteki eşitlik arayışına yönelik aktivist eylemlerini, yeni bir dil ve kurgu aracılığıyla aktarmaktadır" ifadesine yönelik olarak ise öncelikle eşitlik arayışının yeni bir platform üzerinde gerçekleştirildiği vurgulanabilir. Geleneksel yöntemlerden farklı bir şekilde, içeriğini doğrudan kullanıcıların oluşturduğu yeni medyada, farklı bir dil ve kurgu kullanılmaktadır. Minecraft oyun içeriği de bu farklı kurgunun özellikle genç kuşak tarafından oluşturulması yönüyle dikkat çekicidir. Toplumsal bakış açılarını kendi pencerelerinden kurgulayan gençler, Zengin ve Fakir ismi verilen karakterleri ile bu eşitsizliğe ilk etapta dikkat çekmektedirler.

Anlatı yaklaşımı ile analiz edilmeye çalışılan Minecraft Zengin-Fakir oyununa dair dizilerde, "yaşanan, deneyimlenen olayların iletişim kanalları yoluyla aktarımı" düşüncesinden hareket ettiğimizde, söz konusu içeriklerin oluşturulmasında oyuncuların mevcut deneyimlerinin etkisi göz ardı edilmeyecektir. Anlatı analizinin "bir kültürdeki değer yargılarını anlatması" şeklinde bir bakış açısıyla da desteklenen bu düşünce, Zengin'in kötü kalpli olarak nitelendirilmesinde, toplumsal değerlerin etkisini de göstermektedir. Yine anlatı analizinin tutarlılık başlı̆̆ı altında belirtilen "karakterlerin yaptıklarını yapmak için iyi bir sebepleri vardır" ifadesi çerçevesinde içerikleri incelediğimizde, var olduğu ifade edilen eşitsizlik, Fakir'in her zaman ezilen, Zengin'in ise her zaman güçlü kabul edilen toplumsal konumu şeklinde karşımıza çıkmaktadır.

Özetle çalışmaya ilişkin sonuçların aktarılmasının yanı sıra bundan sonraki çalışmalara yönelik önerilerde de bulunmak doğru olacaktır. Bu çalışma dünyada ve Türkiye'de çok sayıda takipçisi bulunan ve çevrimiçi ortamda oynanan Minecraft oyununa 
yönelik olarak, Türkiye'deki kullanıcılar tarafından video paylaşım ağı YouTube'da yayınlanan dizi-skeç içeriklerini incelemiştir. Bundan sonra gerçekleştirilecek çalışmalarda, bu içeriklerin yanı sıra oyunun farklı versiyonlarına ait içerikler incelemeye dahil edilebilir. Bu çalışmanın varsayımına uygun şekilde aktivist mesajları analiz etme amacı dışında, farklı çalışmalarda toplumsal açıdan farklı görünümleri tespit etmek adına da Minecraft oyun içeriği analiz edilebilir. Günümüzün dijital kuşağının (Z Kuşağı) davranışlarını, tutumlarını anlayabilmek adına da bu ve benzer içerikteki oyunlar araștırmacılara yeni bulgular sağlayacaktır.

\section{KAYNAKÇA}

ALPER, K., AYTAN, N. \& ÜNLÜ, S. (2015). Görsel medya çağında çocukların video oyun bağımlılıkları, Ĕgitim ve Öğretim Araștırmaları Dergisi, 4(1): 98-106.

ALSTAD, T., HAINS, G., DUNKIN, J. R., KHMELEVSKY, Y., BARTLETT, R. \& NEEDHAM, A. (2014). "Minecraft computer game simulation and network performance analysis, II International Conferences on Computer Graphics, Visualization, Computer Vision, and Game Technology, Bandung, Indonesia.

ATABEK, N. (1992). Kuramcllara göre anlatı, Kurgu Dergisi, 11: 339-347.

BABACAN, M. E. (2015). Yeni medya bağlamında toplumsal hareketler ve yeni insanın karakter analizi, Folklor/Edebiyat, 21(83): 295-307.

BAĞRIYANIK, M. F. (2018). Dijital Alanın Tipolojileri: Dijital Kültüre Dair Sosyolojik Bir Okuma. Yayımlanmamış doktora tezi. Selçuk Üniversitesi Sosyal Bilimler Enstitüsü, Konya. Yayıncllık.

BAȘTÜRK AKÇA, E. (2007). Kimlik, medya ve temsil. İstanbul: Nobel Akademik

BINARK, M. (2007). Dijital oyunlar: sektör, içerik ve oyuncular, Folklor/Edebiyat, 50 (13): 11-23.

BINARK, M. \& BAYRAKTUTAN-SÜTCÜ, G. (2008). Kültür endüstrisi ürünü olarak dijital oyun. İstanbul: Kalkedon Yayınları.

BINARK, M. \& BAYRAKTUTAN, G. (2011). Dijital oyun kültürü haritasında oyuncular: dijital oyuncuların habitusları ve kariyer türevleri. (Ed). Aslı T. Aydemir, Katılımın" e-hali": Gençlerin Sanal Alemi içinde. İstanbul: Alternatif Bilişim.

BOS, B., WILDER, L., COOK, M. \& O'DONNELL, R. (2014). Learning mathematics through minecraft, Teaching Children Mathematics, 21(1): 56-59.

BOSTAN, B. \& TINGÖY, Ö. (2015). Dijital oyunlar: tasarım gereksinimleri ve oyuncu psikolojisi, AJIT-e: Online Academic Journal of Information Technology, 6(19): 722.

BRAND, J. \& KINASH, S. (2013). Crafting minds in Minecraft, Education Technology Solutions, 55: 56-58.

CAMMAERTS, B. (2015). Social media and activism, The London School of Economics and Political Science Research Online, 1-11.

CASTELLS, M. (2003). The power of identity: the information age: economy, society and culture. Wiley-Blackwell.

CASTELLS, M. (2006). Enformasyon çağı: ekonomi, toplum ve kültür. Çev. Ebru Kılıç. Kimliğin Gücü, İstanbul: Bilgi Üniversitesi Yayınları.

CENGIZ, S. (1997). Alan, zaman, kurallar ve amaç çerçevesinde oyunun neliği üzerine, Folklor/Edebiyat Dergisi, 11: 53-64.

ÇAĞLAR, Ş. \& KOCADERE, S. A. (2015). Çevrimiçi öğrenme ortamlarında oyunlaştırma, Journal of Educational Sciences \& Practices, 14(27): 83-102. 
ÇAKIR, S. Y. (2017). Sosyal medyada dijital aktivist hareketler üzerine kuramsal bir inceleme, Gümüşhane Üniversitesi İletişim Fakültesi Dergisi, 5 (2): 753-783.

ÇALIŞ, A. (2017). J. Baudrillard'ın 'Simülasyon've J. Huizinga'nın ‘Oyun'kuramları üzerinden 'Matrıx'filminin değerlendirilmesi, Yeni Medya Elektronik Dergisi, 1(1): 82-92 DEMIRBAŞ, Y. (2017). Oyun çalışmalarında dijital anlatı ile oyun biçimi karşıtlığı ekseninde süren tartışmalara farklı bir bakıș, Moment Dergi, 4(2): 352-373.

DEMIRTAȘ, H. A. (2003). Sosyal kimlik kuramı, temel kavram ve varsayımlar, İletişim Araștırmaları, 1(1): 123-144.

EKMAN, M. (2014). The dark side of online activism: Swedish right-wing extremist video activism on Youtube, Mediekultur: Journal of Media and Communication Research, 30(56): 79-99.

ERTUNA, Ö. (2006). Yeni dünya düzeni: küreselleşme, Muhasebe ve Finansman Dergisi, (30): 36-45.

EVREN, F. B. (2017). Dijital oyunlarda ideolojinin sunumu: GTA IV örneği, The Turkish Online Journal of Design, Art and Communication - TOJDAC, 7 (2): 264-284.

FLANAGAN, M. (2006). "Making games for social change", AI \& SOCIETY, 20(4): 493505.

GÜLEÇ, K. (2014). Anlatı Çalışmaları ve Yapısalcılık Bağlamında Televizyon Dizileri. Yayınlamış Yüksek Lisans Tezi. Ankara Üniversitesi Sosyal Bilimler Enstitüsü, Ankara

GÜNGÖR, N. (2013). İletişim kuramlar ve yaklaşımlar. Ankara: Siyasal Kitabevi.

HEYWOOD, C. (2003). Baba bana top at. İstanbul: Kitap Yayınevi.

HILL, V. (2015). Digital citizenship through game design in minecraft, New Library World, 116(7/8): 369-382.

HUIZINGA, J. (2006). Homo Ludens, İstanbul: Ayrıntı Yayınları.

INDEPENDENT, Markus Persson: If being that rich is so bad, why not just give it all way? Erişim: 12 Ocak 2019.

https://www.independent.co.uk/news/people/news/markus-persson-if-being-thatrich-issobad-why-not-just-give-it-all-away-10481960.html,

IŞITAN, S. \& TURAN, F. (2014). Çocuklarda dil gelişiminin değerlendirilmesinde bir anlatı analizi yaklaşımı olarak öykü anlatımı, Journal of Educational Sciences \& Practices, 13(25): 105-124.

JAHN, M. (2005). Anlatıbilimin: anlatı teorisi el kitabı. Çev. Bahar Dervişcemaloğlu. Ankara: Dergâh Yayınları.

KAHN, R. \& KELLNER, D. (2004). New media and internet activism: from the 'battle of seattle'to blogging, New Media \& Society, 6(1): 87-95.

KALAFATOĞLU, Ş. T. (2015). Toplumsal hareketler ve politik oluşumlar bağlamında yeni medya aracılığılla politik aktivizm, ODÜ Sosyal Bilimler Araştırmaları Dergisi (ODÜSOBİAD), 5(11): 126-145.

KARAGÖZ, K. (2013). Yeni medya çağında dönüşen toplumsal hareketler ve dijital aktivizm hareketleri, Iletişim ve Diplomasi, 1(1):131-156.

KARAHISAR, T. (2013). Türkiye'de dijital oyun sektörünün durumu. Sanat Tasarım ve Manipülasyon Sempozyumu Bildiri Kitabı, 107-113.

KAYA, M. (2012). Klasik sosyolojik perspektifte modernleșme tartışmaları, Birey ve Toplum Sosyal Bilimler Dergisi, 2(2): 111-130.

KAYMAS, S. (2017). Gerçekten bedava mı? Sosyal paylaşım sitelerinde meta olarak oyun ve maddi olmayan emek diyalektiğine dair bir not, Global Media Journal: Turkish Edition, 8(15): 208-232.

KELLNER, D. \& KIM, G. (2010). Youtube, critical pedagogy, and media activism. The Review of Education, Pedagogy, and Cultural Studies, 32(1): 3-36. 
KOCABAŞ, O. \& ÇETIN, S. (2015). Y gençlik ve dijtal aktivizmi: Ankara Tuzluçayır Örneği. İstanbul Kadir Has Üniversite Yeni Medya Çalışmaları II. Ulusal Kongresi, 26-27 Şubat 2015, İstanbul.

KOÇ, P. (2017). Ana Akım Medyanın İnternet Haber Sitelerinde Çevrimiçi Oyunlara Yönelik Bağımlılık Temsili Yayımlanmamış Yüksek Lisans Tezi, Hacettepe Üniversitesi Sosyal Bilimler Enstitüsü, Ankara.

LEAHY, R. (1981). The development of the conception of economic inequality. I. Descriptions and Comparisons of Rich and Poor People", Child Development, 52 (2): 523 532. 59-66.

LIVINGSTONE, S. (1999). New media, new audiences? New media \& Society, 1(1):

MARX, K. (1968). Toplumsal sınıflar ve sınıf çatışması (Çev. Özer Ozankaya). Ankara Üniversitesi SBF Dergisi, 23(04): 281-299.

MERIÇ, Ö. (2012). Yeni medya, görsel metinler ve aktivizm. Visualist 2012 International Congress on Visual Culture: New Approaches In Communication, Art and Design, Digitalization, Ed. Işıl Zeybek, Deniz Yengin, 1, 221-230, Istanbul Kültür University Publication.

Minecraft, What is Minecraft? Erişim: 28 Aralık 2018. https://minecraft.net/trtr/what-is-minecraft/

Minecraft Zengin Fakir Filmi Gariban Zengin, Erişim: 20 Ocak 2019. https://www.youtube.com/watch?v=P6qWeYNvlFw,

Minecraft Zengin Fakir Kötü Kalpli Zengin, Erişim: 21 Ocak 2019.

https://www.youtube.com/watch?v=NymYcafU6CQ\&t=405s,

MINIBAS POUSSARD, J. \& BASTOUNIS, M. (2008). Kimlik ve sosyal temsiller. Sen benim kim olduğumu biliyor musun? Toplumsal Yaşamda Kimlik İzdüşümleri. Ed. Hülya Uğur Tanrı̈̈ver, İstanbul: Hil Yayınları.

MONTGOMERY, K. C. (2000). Children's media culture in the new millennium: mapping the digital landscape, The Future of Children, 10 (2): 145-167.

NIEMEYER, D.Y. \& GERBER, H.R. (2015). Maker culture and minecraft:

implications for the future of learning, Educational Media International, 52(3): 216-226.

OLGUN, C. (2008). Huizinga ve oyun kavramı, Sosyoloji Notları, 4-5: 22-26.

OVERBY, A. \& JONES, B. L. (2015) Virtual legos: incorporating minecraft into the art education curriculum, Art Education, 68 (1): 21-27.

ÖNGEN, O. (2017). Sosyal medya kullanıcılarının gerçeklik yanılgısı, Yeni Medya Elektronik Dergisi, 1(1): 1-14.

ÖZÇELİK, P. K. (2013). Neoliberal küreselleşme süreci ve yoksulluk, Sosyal ve Beşerî Bilimler Dergisi, 5(2): 417-431.

SAYGINER, Ş. \& TÜZÜN, H. (2017). Programlama eğitiminde yaşanan zorluklar ve çözüm önerileri. Uluslararası Bilgisayar ve Öğretim Teknolojileri Sempozyumu, İnönü Üniversitesi, 24-27 Mayıs, Malatya.

SCHIFTER, C. \& CIPOLLONE, M. (2013). Minecraft as a teaching tool: One case study. In Society for Information Technology \& Teacher Education International Conference (pp. 2951-2955). Association for the Advancement of Computing in Education (AACE).

SCHRADIE, J. (2018). The digital activism gap: how class and costs shape online collective action, Social Problems, 65: 51-74.

SCHREINER, K. (2008). Digital games target social change, IEEE Computer Graphic and Applications, 28(1): 12-17.

SHORT, D. (2012). Teaching scientific concepts using a virtual world-Minecraft, Teaching Science-the Journal of the Australian Science Teachers Association, 58(3): 55-58. 
SERT, N. Y. (2012). Online aktivizm araçları yoluyla oluşturulan etkilerin metafor kullanılarak açıllanması, Akdeniz İletişim, 17:126-140.

SIMMEL, G. (2005). Metropol ve zihinsel yaşam. Şehir ve Cemiyet (Ed. Ahmet Aydoğan). İstanbul: İz Yayıncllık.

SÖZEN, M. (2012). Anlatı mesafesi-anlatı perspektifi kavramları, sinematografik anlatı ve örnek çözümlemeler, Uluslararası Yönetim Íktisat ve İşletme Dergisi, 4(8): 123146.

ŞARDAĞI, E. \& YILMAZ, R. A. (2017). Anlatı kuramı ve reklamda kullanımı: anlatı analizi çerçevesinde bir inceleme, Maltepe Üniversitesi İletişim Fakültesi Dergisi, 4(2): 88133.

TANYAŞ, B. (2014). Nitel araştırma yöntemlerine giriş: genel ilkeler ve psikolojideki uygulamaları, Eleștirel Psikoloji Bülteni, 5: 25-38.

TOPBAȘ, H. \& DOĞAN, A. (2016). Toplumsalın yeni agorası olarak sosyal medya: eleştirel yaklaşım, Gümüşhane Üniversitesi İletişim Fakültesi Elektronik Dergisi, 4(1): 124148.

TOURAINE, A. (2010). Modernliğin Eleştirisi. Çev. Hülya Tufan, İstanbul: Yapı Kredi Yayınları

UÇKAN, Ö. (2012). “Dijital Aktivizm” mi, “Aktivizm” mi? Erişim: 04 Ocak 2018 https://yesilgazete.org/blog/2012/06/01/dijital-aktivizm-mi-aktivizm-mi-ozguruckan/

UŞTUK, O. (2016). Așk örüntüleri üzerine bir anlatı analizi, Anadolu University Journal of Social Sciences, 16(3): 59-69.

WEBER, S. \& MITCHELL, C. (2008). Imagining, keyboarding, and posting Identities: young people and newmedia technologies. Youth, Identity, and Digital Media. Ed. David Buckingham. Cambridge, MA: The MIT Press, 25-48. doi:10.1162/dmal.9780262524834.025

WILLIAMS, D. (2006). Groups and goblins: the social and civic impact of an online game, Journal of Broadcasting \& Electronic Media, 50(4): 651-670.

YEGEN, C. (2014). Bir dijital aktivizm biçimi olarak slaktivizm: change.org örneği, Karadeniz Teknik Üniversitesi İletişim Araștırmaları Dergisi, 1(8): 84-108.

YEGEN, C. \& AYDIN, B. O. (2018). Postmodern bir kimlik olarak veganlık ve bir çevrimiçi vegan ağının analizi, Ileti-s-im, (28): 91-11.

YÜCEL, G. \& ŞAN, Ş. (2018). Dijital oyunlarda bağımlılık ve şiddet: blue whale oyunu üzerinde bir inceleme, AJIT-e: Online Academic Journal of Information Technology, $9(32)$.

\section{Summary}

In recent years, it is observed that generally addiction and cyber bullying subjects have been prominent in the studies about the relationship of internet usage with young people. This study aims to approach the subject in a different context. For this reason, Minecraft, which is a computer game that places the young generation in an active position in terms of producing new media content and attracts attention all around the world, has been selected as a sample. In this study, Minecraft's rich and poor content, which is also the scope of the study, in the video sharing website YouTube Turkey was studied through the structural narrative analysis method.

This study entitled, "Seeking for Equality in Online Games: "The Poor Peasant against the Black-Hearted Rich Man in Minecraft YouTube Series Content" interprets the perspective-based on the resistance and struggle for denominational inequality problem in the social life, carried out in a different platform in new media content - with narrative 
analysis method. The aim of the study is to reveal the fictionalization of social class inequality in a content created by users, pursuant to identity representation. Within this scope, the series-skit contents for Minecraft named online game shared in YouTube sharing network, recently took place often in the agenda as well as in curriculums in schools, were examined.

The narrative analysis method, underlying that "The characters have reasonable reasons to do what they have done", in this study, aims to analyze the identity representation of Rich and Poor characters in the Minecraft game content especially fictionalized by children and the youth. After the analysis, when the content fictionalized by users who have in a constant struggle against the rich, with the emphasis of "the black-hearted rich" was examined, it was seen that the squash of the poor against the rich' oppression and their resistance against that had been conveyed by these contents. The new media content today should also be considered from one of these environments, for the individual who represents and reflects their social identities in different environments. The individual, having been in the position of watcher, listener, or reader, can form their own content in the interactive structure in the new media, without being capable of intervening to the content of the conventional media. Online games also draw attention as an important pattern, especially at the point of creation of the content by the youth. Besides, it was reported in this study that these games, differently from the entertainment content wherein only leisure time is spent, are starting to be considered as a representative environment in the subject of digital activism as well, depending on the contents of the games.

In addition to the information about activism, digital activism issues in the new media and social class and identity representation issues in online games; information about Minecraft game selected to be examined in the study were given under the title of the study's conceptual framework. Then information about the method of the study was given. The narrative analysis method, aiming to analyze the fictions of narrators and performed for enciphered experiences in story format, was chosen for the analysis of Minecraft the Rich the Poor series-skits fully created by the fictions of users in YouTube video-sharing network. In the study wherein two different contents were analyzed, and fiction in the way of the rich the poor was realized for social classes, the struggle and resistance of the squashed poor against the rich was brought into the forefront in this fiction, making the rich's image in a negative way. 